\title{
Contusugene ladenovec
}

National Cancer Institute

\section{Source}

National Cancer Institute. Contusugene ladenovec. NCI Thesaurus. Code C2471.

A replication-defective adenoviral-CMV vector that encodes a wild-type p53 gene.

Contusugene ladenovec induces tumor cells that have been transfected with the vector

to produce wild-type p53, a tumor suppressor gene that is deleted or mutated in a significant number of cancers. In transfected tumor cells, the wild-type p-53 gene product exerts an antitumor effect by blocking cell cycle progression at the G1/S regulation point, activating DNA repair proteins in the presence of DNA damage, and initiating apoptosis when DNA damage is irreparable. ( $\mathrm{NCl04)}$ 